\title{
ÉREM- ÉS KINCSLELET KISKUNMAJSA-JONATHERMÁL LELŐHELYEN
}

\author{
V. SZÉKELY GYÖRGY-NAGY BALÁZS*
}

\begin{abstract}
2016-ban Kiskunmajsán egy régészeti leletmentés során egy éremlelet, valamint egy kincslelet került elö. A két leletegyüttes pénzeinek meghatározását V. Székely György végezte el. Jelen tanulmányunk célja a numizmatikai emlékanyag rövid ismertetése, amivel a feltáráson elókerült régészeti jelenségek keltezéséhez kívánunk hozzájárulni.
\end{abstract}

Kulcsszavak: tatárjárás, numizmatika, éremlelet, kincslelet

A coin hoard and a treasure trove were found on a rescue excavation at Kiskunmajsa in 2016. The coins of both hoards were defined by György $V$. Székely. This paper provides a short description of these finds to assist the chronology of the archaeological phenomena.

Keywords: Mongol invasion, numismatics, coin hoard, treasure trove

\section{Kiskunmajsa-Jonathermál 1. felület}

A felületről 201 érem került elő, ${ }^{1}$ melyekről a feltárás során bebizonyosodott, hogy azok egy egységet alkotnak, így éremleletként kezelendők. ${ }^{2}$

A kézirat beérkezett: 2017. december 2.

* †V. Székely György: Kecskeméti Katona József Múzeum. Nagy Balázs: Ferenczy Múzeumi Centrum. H-2000 Szentendre, Fó tér 2-5.; Kecskeméti Katona József Múzeum. H-6000 Kecskemét, Bethlen krt. 1; e-mail: nagyb. archeonumis@gmail.com

1 Itt szeretném megköszönni Rosta Szabolcsnak, hogy lehetőséget biztosított számomra a Kiskunmajsa-Jonathermál lelőhelyről előkerült leletegyüttesek szakmai gondozására, ismertetésére. Munkám során ösztönző ötletekkel és hasznos tanácsokkal látott el, amiket ezúton is nagyon köszönök. Továbbá köszönettel tartozom Laszlovszky Józsefnek a lektori véleményben megfogalmazott gondolatokért.

2 A leletegyüttesek részletes ismertetésére egy külön tanulmányban kívánok sort keríteni. A feltárás során eltérő összetételú leletegyüttesek kerültek napvilágra, melyek numizmatikai terminusát a következókben adjuk. Míg a pénzekből álló leletegyüttest éremleletnek, addig az érmek mellett egyéb tárgyakat, ékszereket is tartalmazót kincsleletnek
Az éremlelet elókerülési helye nagyrészt másodlagos, amit a mezőgazdasági múvelés részben bolygatott. A helyszínen végzett régészeti megfigyelések szerint az éremlelet a 7. jelenségbe tartozó 25-35 év közötti felnőtt nőhöz tartozhatott. Bár a leletegyüttes tárolására szolgáló maradványok nem kerültek elő, a pénz mennyiségéből adódóan textilerszényre gondolhatunk. A pénzek egykoron címlet szerint voltak rendezve, amire az összetapadásukból következtethetünk. Az éremleletben egyaránt találunk magyar $(5 \mathrm{db})$ és külföldi (21 db) denárokat, valamint magyar veretú lemezpénzeket $(175 \mathrm{db})$ is (1. kép).

A magyar veretek 5 db H.69 denárból és 175 db H.195 típusú lemezpénzból állnak. ${ }^{3}$ A külföldi veretek száma a magyarokéhoz képest elenyészőnek tûnik, csekély mennyiségük mellett mégis nagyon változatos típusok alkotják. Megtaláljuk köztük a tatárjárást megelőző több mint fél

nevezzük. A leletegyüttes fogalmának használatakor a vonatkozó részben ismertetett pénzek vagy egyéb vagyontárgyak (ékszerek) összességét értjük.

3 Huszár 1979. 


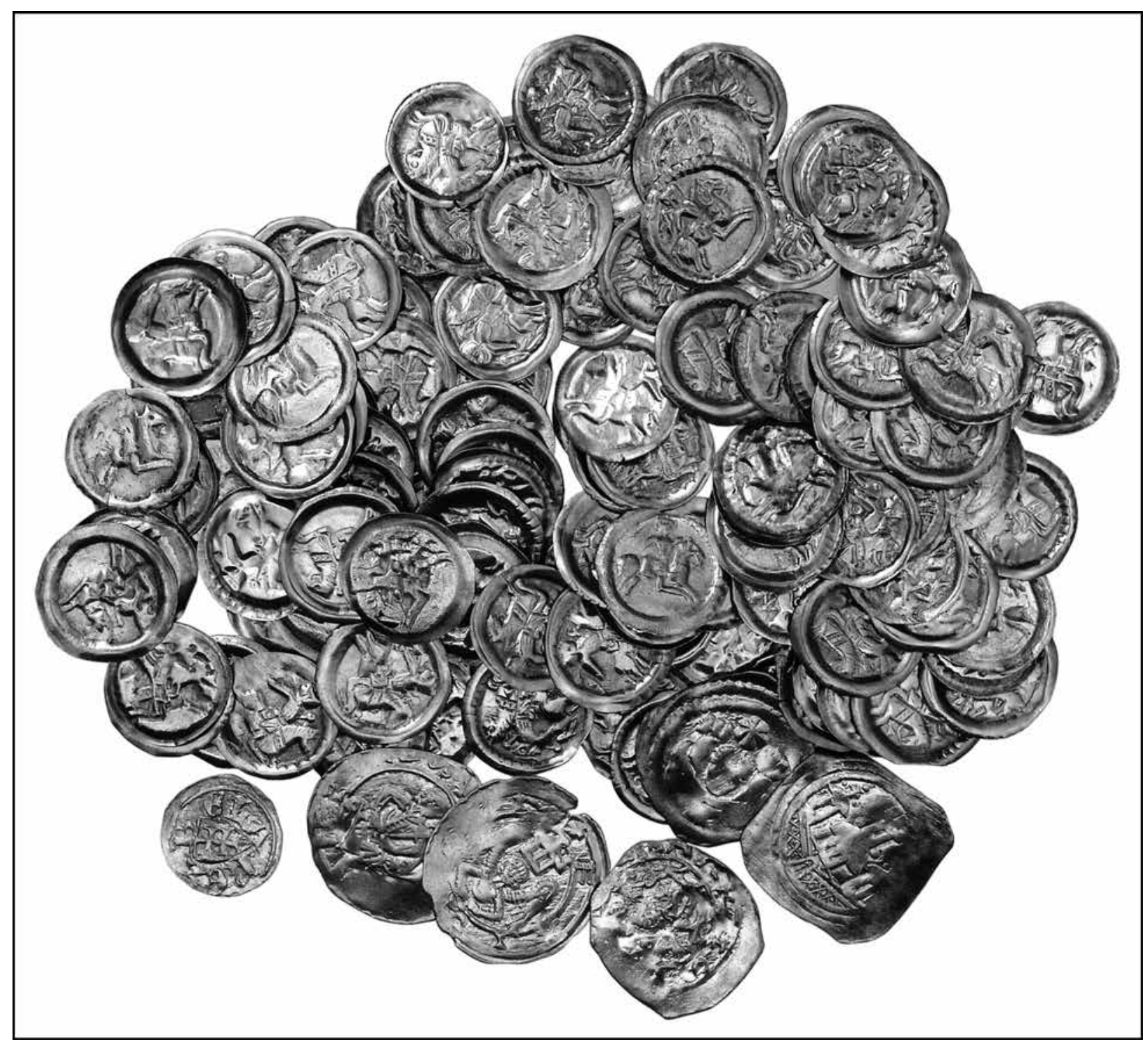

1. kép. Kiskunmajsa-Jonathermál. Éremlelet az 1. felületról

Fig. 1. Kiskunmajsa-Jonathermál. Coin hoard of Site 1

évszázadon keresztül beáramlott friesachi denárokat (19 db), valamint az azok mintájára készült grazi és trieszti vereteket is.

Amennyiben az éremlelet záródását kívánjuk meghatározni, úgy esetünkben a külföldi veretek jelenthetik a megoldást. A legkésőbbi veretek között említhetjük II. Eberhard salzburgi érsek 1220/1230 között kibocsátott pettaui veretét (Cg1), valamint VI. Leopold stájer herceg 1220/1230 között vert pettaui (Cg5) és grázi (D3) denárjait. ${ }^{4} \mathrm{~A}$ záródás idejére keresett válasz során nem mehetünk el amellett sem, hogy az éremlelet jelentős részét a már fentiekben is említett H.195 lemezpénz teszi ki. Bár a kutatás jelen állása mellett nehéz állást foglalni ezek kibocsátási

4 КосH 1994. idejét illetően, véleményünk szerint az utóbbi időkben előkerült leletegyüttesek újabb és újabb adalékkal szolgálhatnak e kérdés megválaszolásában. ${ }^{5}$ Azonban a numizmatikai kutatás jelen

5 Az utóbbi évtizedekben megjelent érem- és kincsleletek összetételének vizsgálatával foglalkozó számos tanulmány fókuszában a magyar lemezpénzek és a H.69 denár keltezési nehézségeinek összefoglalásával, illetve megoldási javaslatokkal találkozhatunk. A témával kapcsolatban az utóbbi évtizedben több fontos tanulmány is született: V. SzÉKELY 1994, 118; KovÁCS 1997, 81-82; KöRMENDI 2011, 73-83; GYÖNGYÖSSY 2012, 21; KÖRMENDI 2013, 71-81; V. SZÉKELY 2014, 331-332. Jelen tanulmánynak nem célja a fentiekben említett veretek kibocsátóhoz kötése és a szerteágazó kronológiai kérdések megválaszolása. Ezzel szemben feladatunk a feltáráson előkerült érem- és kincslelet rövid ismertetése, ami újabb támpontot szolgáltathat a fentiekben említett veretek kibocsátási idejére vonatkozóan. 


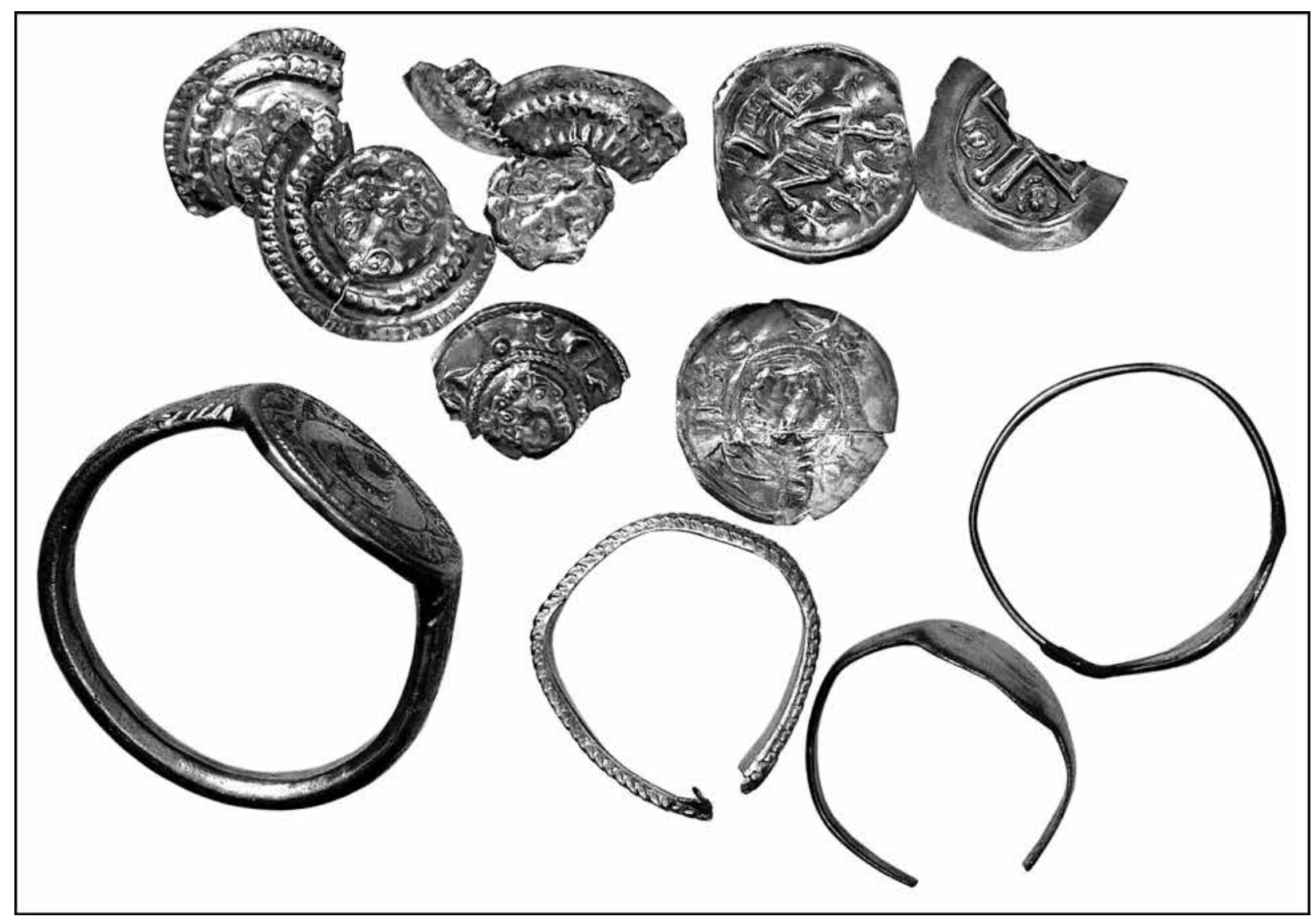

2. kép: Kiskunmajsa-Jonathermál. Kincslelet a 2. felületről

Fig. 2. Kiskunmajsa-Jonathermál. Treasure trove of Site 2

állása mellett biztosabbnak túnik, ha a külföldi veretekre támaszkodunk. Így a záródási idő az 1220-1230 közötti évekre határozható meg.

\section{Kiskunmajsa-Jonathermál 2. felület}

A kincslelet négy ezüstgyứrúből, valamint $36 \mathrm{db}$ pénzból áll. A gyưrúket méret szerint egymásba helyezték, majd a legkisebb átmérőjú karika nyitott (állítható) gyưrújébe $8 \mathrm{db}$ lemezpénzt helyeztek (2. kép). A pénzek között az alábbi típusokat találjuk meg: H.191, H.192, H.199, H.200, valamint egy töredékes volta miatt bizonytalanul meghatározhatót H.198? is. A kincslelet érméinek többségét a külföldi veretek teszik ki $(22 \mathrm{db})$. A magyar veretek között a legkorábbi a H.186 típusú anonim denár, de megtaláljuk a H.69 királyneves (BELA REX) denárt is. A gyưrúkbe helyezett lemezpénzeken túl a kincslelethez továbbiak is tartoznak, amelyek között a H.195 (2 db) és a H.200 típusokat különböztethetjük meg. A külföldi veretek 21 friesachi típusú és egy angol denárból állnak (3. kép). ${ }^{6} \mathrm{Az}$ angol pénzek Magyarország területére kerülésének okául elsősorban két eseményt említhetünk, amiket Gyöngyössy Márton a III. Béla idejéből fennmaradt jövedelem-összeírások kapcsán említ. ${ }^{7}$ Az idegen veretek között a legkésőbbiek közé sorolható a Ca20 és a Ca21 típus. Ezek alapján a kincslelet záródását az 1228-1230 közötti évekre tehetjük.

A fentiekben röviden ismertetett leletegyüttesek legfőbb sajátossága, hogy összetételük a tatárjárás lelethorizontjára jellemzó verettípusokból áll, illetve az előkerült pénzmennyiség csupán a mindennapi életben adódó kiadások fedezésére lehetett elegendő. Így egyik esetében sem

6 Az angol pénzek magyarországi forgalmával kapcsolatos kutatási eredményekről összefoglalóan utóbb Jablonkai Dávid tartott előadást az MTA BTK TTI Lendület Kutatócsoport által megrendezett "Veretek és leletek" konferencián (2017. december 5.) „Londontól - Jeruzsálemig: Gondolatok néhány 12-13. századi éremlelethez" címmel. Kutatási eredményei a téma kutatlanságából kifolyólag hiánypótlónak számítanak.

7 GYÖNGYÖSSY 2012, 21; GYÖNGYÖSSY 2015, 125. 


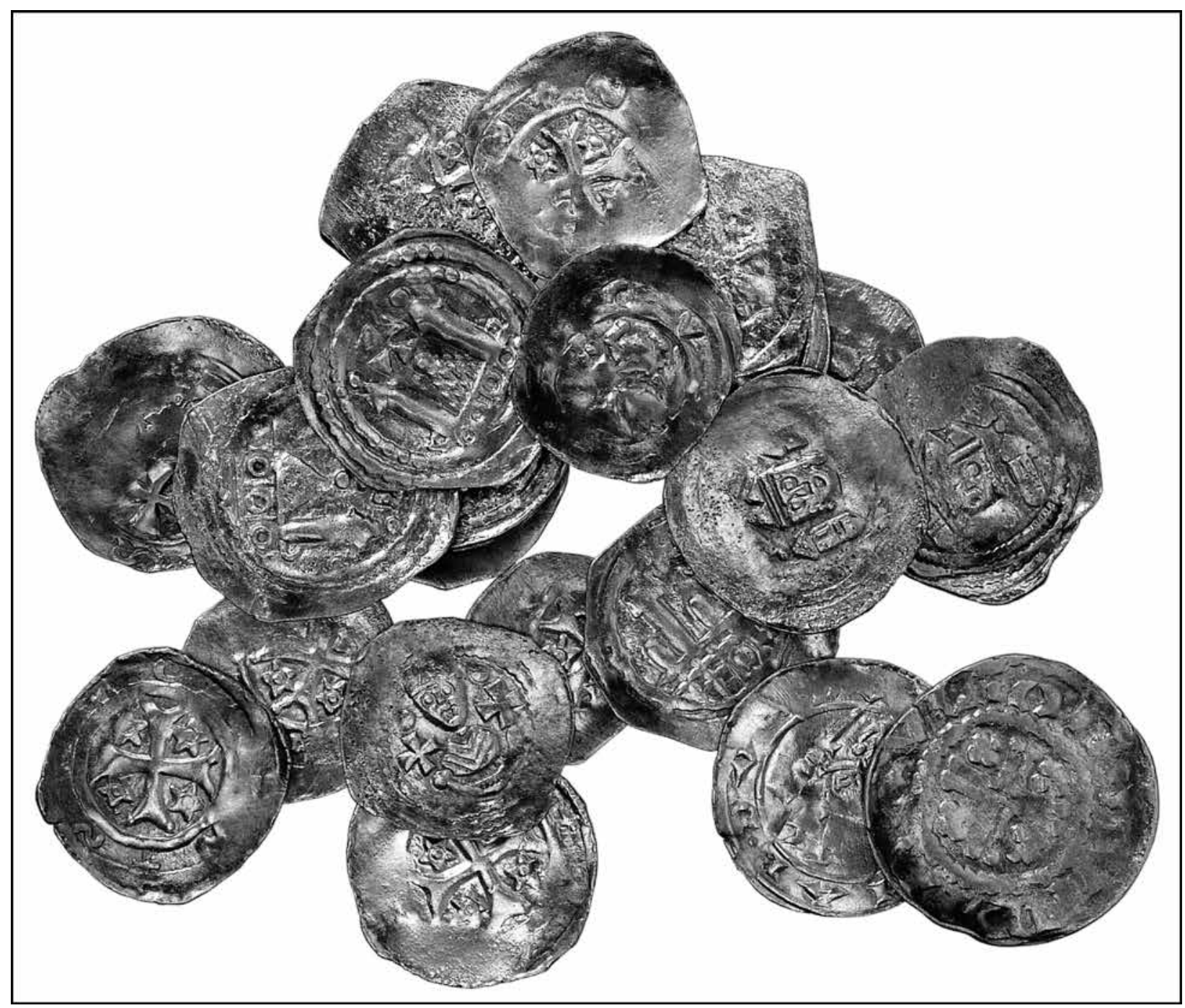

3. kép. Kiskunmajsa-Jonathermál. A kincslelet gyürüi és a beléjük helyezett érmek

Fig. 3. Kiskunmajsa-Jonathermál. Rings and coins of the treasure trove

beszélhetünk egyfajta tudatos felhalmozásról. Az érem- és kincslelet záródása kapcsán a magyar veretekre továbbra sem támaszkodhatunk. A numizmatikai kutatás jelenlegi állása mellett a magyar pénzekkel továbbra sem tudunk élesen keltezni, bár az ez irányú törekvések az utóbbi években sok új eredményt hoztak. ${ }^{8}$ Fontosnak tartjuk kihangsúlyozni, hogy a külföldi veretek magyarországi jelenlétét elsősorban az Itália felől érkező kereskedők idézték elö. ${ }^{9}$ Ezt a tényt tovább fejtegetve megállapíthatjuk, hogy a tatárjárás horizontjára helyezhető, külföldi pénzeket tartalmazó érem- és kincsleletek záródása sokkal inkább az egykoron létrejött adásvétel idejével van összefüggésben, mintsem az elrejtéssel. Mindemellett azt sem szabad figyelmen kívül hagyni,

8 KÖRMENDI 2011; GYÖNGYÖSSY 2012; KÖRMENDI 2013; V. SZÉKELY 2014

9 POHL 1975, 14-15. hogy a külföldi kereskedők nem feltétlenül a legfrissebb veretekkel rendelkeztek. ${ }^{10}$ A továbbiakban kérdést vethet fel, hogy a kereskedelmi ügyletek révén az emberek tulajdonába került több száz vagy akár több ezer darab külföldi pénz milyen arányban egészítette ki a mindennapi pénzforgalmat. Amennyiben elfogadjuk azt a tényt, hogy a friesachi típusú denárok érték- és időtállóak voltak a magyar pénzekkel szemben, úgy a külföldi veretek csak lassú és kismértékú forgalmát feltételezhetjük. ${ }^{11}$ Ebből kifolyólag egyáltalán nem meglepó, hogy az 1241-42. évi tatár-

10 NAGY 2015, 279-280.

11 A külföldi pénzeket tartalmazó tatárjárás kori leletegyüttesekben a legkorábbi veretek I. Eberhard (1147-1164) pénzkibocsátásából is származhatnak, de e tekintetben a leggyakrabban az 1170 és kb. 1200 között vert pénzek említhetők. Ezek alapján megállapítható az is, hogy a friesachi típusú denárokat kibocsátó területeken 1230-ban még javában forgalomban voltak az 1147 és 1200 között vert denárok. 
járást a Magyarország területéról eddig előkerült mintegy 100 leletegyüttes túlnyomó többsége általában egy évtizedes záródási késéssel jelzi. ${ }^{12}$ A fentiekben megfogalmazott gondolatokkal alá- támasztva a Kiskunmajsán elókerült érem-, illetve kincslelet földben maradását a tatárok okozta 1241. évi pusztításokkal hozhatjuk összefüggésbe. $^{13}$

\section{IRODALOM}

GYÖNGYÖSSY MÁRTON

2012 Magyar pénztörténet 1000-1540. Budapest, 2012.

2015 A középkori magyar pénzverés területi szakigazgatási szervei. A pénzverőkamara-rendszer fejlődésének vázlata (Die territoriale Verwaltung der mittelalterlichen Münzprägung in Ungarn. Ein Abriß der Entwicklung des Münzkammersystems). Numizmatikai Közlemények (Budapest) 112-113 (2013-2014), 125-152.

Huszár, LAJOS

1979 Münzkatalog Ungarn. Von 1000 bis Heute. Budapest.

KOCH, BERNHARD

1994 Corpus Nummorum Austriacorum (CNA). Band 1. Mittelalter. Wien.

KovÁcs LÁsZló

1997 12. századi anonim denárok. Századok (Budapest) 131, 75-104.

KÖRMENDI TAMÁS

2011 A magyar királyok kettőskeresztes címerének kialakulása. Turul (Budapest) 84, 73-83.

2013 Még egyszer III. Béla állítólagos címeres denárjáról és brakteátáiról. Numizmatikai Közlemények

NAGY BALÁZS (Budapest) 110-111 (2011-2012), 71-81.

2013 Tatárjárás kori pénzleletek Pécsről. In: Varga Máté (szerk.): Fiatal Középkoros Régészek IV. Konferenciájának Tanulmánykötete. Kaposvári Rippl Rónai Múzeum Közleményei 2. Kaposvár, 227-238.

2015 Tatárjárás kori pénzleletek a Dél-Dunántúlról. In: Szőllősy Cs.-Pokrovenszki K. (szerk.): Fiatal Középkoros Régészek VI. Konferenciájának Tanulmánykötete. Székesfehérvár, 277-285.

POHL ARTÚR

1975 A friesachi denárok és magyarországi forgalmuk oka. Az Érem (Budapest) 32:2, 13-19.

То́тH CSABA

2007 A tatárjárás korának pénzekkel keltezett kincsleletei. In: Ritoók Á.-Garam É. (szerk.): A tatárjárás. V. SZÉKELY GYÖRGY Kiállítási katalógus. Budapest, 79-90.

1994 Megjegyzések a késő Árpád-kori éremleletek keltezéséhez. In: Nagy Á. (szerk.): A numizmatika és a társtudományok (Szeged) 3, 115-124.

2014 Tatárjárás és numizmatika. Egy történelmi katasztrófa pénzforgalmi aspektusai. In: Rosta Sz.-V. Székely Gy. (szerk.): „Carmen miserabile”. A tatárjárás magyarországi emlékei. Tanulmányok Pálóczi Horváth András 70. születésnapja tiszteletére. Kecskemét, 331-334.

\section{COIN HOARD AND TREASURE TROVE AT KISKUNMAJSA-JONATHERMÁL}

\begin{abstract}
GYÖRGY V. SZÉKELY†
In 2016 a rescue excavation was managed in Kiskunmajsa, due to the numerous silver coins and human bones ploughed out from upper layers of the soil. According to the density of surface finds, two excavation territories were pointed (I., II. surface). In the first excavation territory, a coin hoard containing 201 silver coins was discovered, which probably was in a purse of a 25-35 yrs female. In the second excavation territory, a treasure trove including jewelries and coins was found in a semisubter-

12 Tо́тн 2007, 79-90; NAGY 2013, 227-238.

13 A fentiekben bemutatott leletegyüttesek különlegessége, hogy bár mindkettő egy azonos időben és helyen végbement pusztítás nyomát őrzi, az érem- és a kincslelet záródási időpontja mégis eltérő. A külföldi veretek alapján az 1 . felület éremlelete az 1220/1230, míg a 2. felület kincslelete az
\end{abstract}

ranean house, with a content of 36 silver coins and four silver rings. Both hoards consist of Hungarian and foreign coins as well. Among the Hungarian coins, there are mainly sheet coins and denarius coins. The foreign ones consist of Friesach type coins and English denarius. According to the foreign hoards, their closing dates are between 1220-1230 and 1228-1230. As a conclusion, both coin hoards can be related to the Mongol invasion around 1241.

1228/1230 közötti években záródik. Ezek a tények csak tovább erósítik a zárógondolatban megfogalmazott, külföldi veretre vonatkozó következtetéseket, valamint azt is, hogy a jelenlegi ismereteink mellett túlzás lenne elvárni a tatárjárás kori leletegyüttesektől, hogy a záróveretek akár az 1241. vagy az 1242. évi pusztításokat élesen keltezzék. 